\title{
LOS PACTOS DE SOCIOS EN EL DERECHO COLOMBIANO*
}

\section{SHAREHOLDERS AGREEMENTS IN COLOMBIAN LAW}

\author{
Magda Liliana Camargo-Agudelo** \\ Fecha de recepción: 2 de marzo de 2017 \\ Fecha de aceptación: 20 de marzo de 2017 \\ Disponible en linea: 30 de noviembre de 2017
}

\section{Para citar este artículo/To cite this article}

Camargo Agudelo, Magda Liliana, Los pactos de socios en el derecho Colombiano, 135 Vniversitas, 19-52 (2017). https://doi.org/10.11144/ Javeriana.vj135.psdc

doi:10.11144/Javeriana.vj135.psdc

Este artículo es resultado de la investigación realizada por la autora que condujo a la preparación de la tesis de magíster en Derecho de la Universidad Sergio Arboleda.

** Abogada de la Universidad de La Sabana. ORCID: 000-001-5027-9757. Especialista en Derecho Constitucional, Universidad del Rosario. Magíster en Derecho, Universidad Sergio Arboleda. Integrante del Centro de Estudios de Derecho Comparado, http://www.cedclaw.com. Contacto: magdalilianaca@gmail.com 


\section{RESUMEN}

Este artículo busca analizar el régimen de los pactos parasocietarios contenido en el artículo 70 de la Ley 222 de 1995 y en el artículo 24 de la Ley 1258 de 2008, con el objetivo de determinar su alcance y de esta forma, comprender la regulación de estos pactos en el derecho comercial colombiano y la manera como estas normas se relacionan con las reglas generales en materia de obligaciones, contratos y sociedades, de tal modo que se busca sostener la posibilidad de celebrar pactos de socios en todos los tipos societarios y no solamente en la sociedad anónima y por acciones simplificada. También se busca identificar los principales aspectos objeto de debate, para lo cual el trabajo se basa no solamente en un análisis normativo, sino también doctrinal, jurisprudencial e incluye la referencia a las interpretaciones que ha realizado la Superintendencia de Sociedades tanto en conceptos como en decisiones judiciales relacionadas con pactos societarios.

Palabras clave: Pactos de socios; derecho de sociedades 


\section{ABSTRACT}

This paper analyzes the system of shareholders agreements contained in Article 70 of Law 222 of 1995 and Article 24 of Law 1258 of 2008, in order to determine its scope and thus understand generally the regulation of these agreements in the Colombian commercial law and the way how are you standards relate to the general rules on obligations, contracts and partnerships, thereby seeks to sustain the possibility to conclude agreements partners in all types of companies and not only in the corporation and simplified stock. It also seeks to identify the main issues under discussion for which the work is based not only on a policy analysis, but also doctrinal, jurisprudential and includes reference to the interpretations made by the Superintendencia de Sociedades both concepts and judicial decisions related corporate agreements.

Keywords: Shareholders agreements; company law

\section{SUMARIO}

InTROduCCiÓN.- I. Los PACTOS DE SOCIOS EN LA Ley 222 DE 1995.- $A$. La limitación a la sociedad anónima y su eventual extensión a otros tipos societarios.- B. La restricción subjetiva y la sanción por su violación.- C. El alcance objetivo del acuerdo.- D. Los requisitos de forma.- E. La duración del acuerdo.- F. El incumplimiento del acuerdo.- II. Los PACTOS DE SOCIOS EN LA LEY 1258 DE 2008.- A. El factor subjetivo y objetivo de aplicación.B. Los requisitos de forma, oponibilidad y duración.- $C$. Sanciones por inobservancia del acuerdo.- CONCLUSIONES.- BiBLIOGRAFÍA. 


\section{INTRODUCCIÓN}

La relación que surge entre quienes acuerdan conformar una sociedad, se asume que debe estar regulada en los estatutos societarios ${ }^{1}$. De hecho, es la función que la doctrina le ha señalado a la escritura social, al afirmar que la misma debe "...contener las estipulaciones suficientes para determinar el régimen de la sociedad que se constituye, según su forma o tipo legal"'2. En efecto, si se revisa el contenido del artículo 110 del Código de Comercio colombiano, en él se señalan todos los aspectos que deberá contener la escritura pública de constitución de la sociedad, en especial aspectos como el objeto, el capital social, la forma de administrar la sociedad, la organización y el funcionamiento de los máximos órganos de gobierno societario, la aprobación de balances, la distribución de utilidades y reservas, la forma de liquidar la sociedad, la manera de solucionar las diferencias que surgen entre los asociados entre sí o para con la sociedad, la representación legal de la misma, las facultades y obligaciones del revisor fiscal, etc. La norma, además, establece en el numeral 14 la posibilidad de incluir otros pactos compatibles con la índole de cada tipo de sociedad, que los asociados estipulen para regular las relaciones a que da origen el contrato. Algo similar, con sus diferencias puntuales, establece el artículo 5 de la Ley 1258 sobre sociedad por acciones simplificada.

Según esto, entonces, al parecer son los estatutos societarios el escenario para pactar las reglas que conducirán las relaciones de los socios. De hecho, así se ha considerado tradicionalmente en la doctrina nacional; por ejemplo, Gabino Pinzón, al referirse a la escritura social, indica que esta está destinada a cumplir dos funciones esenciales: dar autenticidad al contrato social y tipificar la sociedad. Al explicar el alcance de esta función, el autor señala que el fin de las estipulaciones que debe contener la escritura según el artículo 110 del Código de Comercio es "... regular de forma clara y completa las relaciones derivadas del contrato social..."3. En este contexto, el artículo 118 del Código de Comercio establece

1 Luis Carlos Neira-Archila, Apuntaciones generales al derecho de sociedades, 42 (Temis, Bogotá, 2006).

2 Gabino Pinzón, Sociedades comerciales, vol. 1. Teoría general, 102 (Temis, Bogotá, 1988).

3 Gabino Pinzón, Sociedades comerciales, vol. 1. Teoría general, 101 (Temis, Bogotá, 1988). 
que "Frente a la sociedad y a terceros no se admitirá prueba de ninguna especie contra el tenor de las escrituras otorgadas con sujeción a los artículos 110 y 113, ni para justificar la existencia de pactos no expresados en ella".

De todos modos, en la práctica societaria aparecen acuerdos celebrados entre los socios, que suelen ser llamados de diversa forma por la doctrina: acuerdos de socios, convenios de socios, pactos de socios o accionistas, acuerdos parasocietarios, pactos de sindicación de acciones, etc., con el fin de regular las relaciones entre ciertos grupos de socios ${ }^{4}$.

El objetivo de este trabajo es analizar la regulación colombiana sobre los pactos de socios con el fin de reconocer su alcance y contenido, buscando de esta forma establecer si es posible pactarlos en todos los tipos societarios y además, verificar si es admisible o no en el derecho colombiano, la celebración de pactos con objetos diferentes a los señalados en las correspondientes normas legales.

El método seguido para el desarrollo y estructuración de este trabajo ha sido el dogmático. A partir de ello se han analizado la legislación y la doctrina ${ }^{5}$. En cuanto a la jurisprudencia, se han

4 Alfredo L. Rovira, Pactos de socios, 1 (Astrea, Buenos Aires, 2006). Dado que todas las señaladas son denominaciones empleadas por la ley, la doctrina y la jurisprudencia, a lo largo de este escrito se empleará cualquiera de ellas.

5 Las referencias doctrinales en Colombia sobre los pactos parasocietarios son recientes y relativamente escasas. En las obras generales de derecho de sociedades, hay referencias en FrANCISCO REYES-VILLAMIZAR, Reforma al régimen de sociedades y concursos, 121 ( $2^{\mathrm{a}}$ ed., Temis, Bogotá, 1999). FranCISCO Reyes-Villamizar, Derecho societario, I, 636-654 (3ª ed., Temis, Bogotá, 2016). Néstor Humberto Martínez-NeIra, Cátedra de derecho contractual societario, Regulación comercial y bursátil de los contratos societarios, 134-144 (2ª ed., Legis, Bogotá, 2014). ENRIQue Gaviria-GutiÉrRez, Apuntes sobre el derecho de las sociedades, 59 (Señal Editora, Medellín, 2004). Y también los siguientes trabajos monográficos y artículos: PABLO ANDRÉs CóRDOBA-AcosTA, El derecho de sociedades y el gobierno de la sociedad anónima: el interés social, órganos, accionistas y administradores, 515-531 (Universidad Externado de Colombia, Bogotá, 2014). Felipe Cuberos de las Casas, Sociedad por acciones simplificada (SAS). Novedades, aciertos y desaciertos, 113-118 (Pontificia Universidad Javeriana, Ibáñez, Bogotá, 2012). DAVID ANTONIo BELtrÁN-DÁvila, Apuntes sobre la obligatoriedad de los acuerdos de accionistas, 41 Foro de Derecho Mercantil, 37-65 (2013). Ana María CorreaGonZÁLEZ, Los acuerdos de accionistas bajo la Ley 1258 de 2008 (Pontificia Universidad Javeriana, Bogotá, 2011). Disponible en: https://repository.javeriana.edu.co/bitstream/handle/10554/9990/ CorreaGonzalezAnaMaria2011.pdf?sequence=1. Lina Henao, Los pactos parasociales, 25 Revista de Derecho Privado, 179-217 (2013). Disponible en: http://revistas.uexternado.edu.co/index.php/ derpri/article/view/3600/3778. Darío Alejandro Mejía-Mejía, Los acuerdos de accionistas. Evolución y aplicación en Colombia, 52 Revista de Derecho Privado, Universidad de los Andes, 1-30 (2014). Disponible en: https://derechoprivado.uniandes.edu.co/components/com_revista/archivos/ derechoprivado/pri538.pdf. Jorge OviEdo-Albán, Flexibilización de la constitución de sociedades en Colombia, en Modernización del derecho societario, 59-82 (MARÍA Fernanda VÁsQuez-PALMA \& José Miguel Embid-Irujo, dirs., Thomson Reuters, Santiago, 2015), aunque este último no se publicó en Colombia. Algunos otros autores no hacen mayores referencias a ellos, como LiSANDRO 
tenido en cuenta los casos conocidos hasta la fecha que han sido objeto de decisión en Colombia.

En el derecho colombiano, los pactos de socios están regulados en tres normas, como el artículo 70 de la Ley 222 de 1995; el artículo 43 de la Ley 964 de 2005 y el artículo 24 de la Ley 1258 de 2008. En los párrafos siguientes se procederá a analizar el alcance y requisitos de cada una de estas normas, en busca de sentar algunas bases para el análisis de la viabilidad de otros pactos, no contemplados en ellas pero sí admitidos en el derecho colombiano ${ }^{6}$.

El trabajo está dividido de la siguiente manera: en un primer punto, se analiza el alcance y requisitos de los pactos societarios a partir de la regulación de los pactos societarios contenida en la Ley 222 de 1995. A continuación, se hace lo propio en relación con la Ley 1258 de 2008. Finalmente se incluyen las principales conclusiones y bibliografía.

\section{LOS PACTOS DE SOCIOS EN LA LEY 222 DE 1995}

La Ley 222 de 1995 reguló los pactos parasocietarios en el artículo $70^{7}$. La norma amerita varios comentarios en relación con su alcance, objeto y requisitos:

Peña-Nossa, De las sociedades comerciales, 265 (6 $6^{\mathrm{a}}$ ed., Temis, Bogotá, 2011), quien tan solo se refiere de manera descriptiva a los acuerdos de socios en la sociedad por acciones simplificada, pero sin mencionar las reglas de la Ley 222 sobre el particular.

6 Sobre este punto, cabe observar que la Superintendencia de Sociedades ha conceptuado que el acuerdo parasocietario es un contrato atípico. Colombia, Superintendencia de Sociedades, Oficio 220-19417, 15 de abril de 1997, Doctrinas y conceptos jurídicos 1997, 34-39, 37 (Superintendencia de Sociedades, Bogotá, 1997). De todas maneras, esta concepción debe ser matizada, pues tal acuerdo está parcialmente tipificado, tanto en el artículo 70 de la Ley 222 como en el 24 de la Ley 1258 con los requisitos y efectos que en cada caso tales normas les asignan. Ahora, tal concepción es admisible para los pactos cuyo objeto no encaje en las modalidades admitidas por tales disposiciones.

7 El texto de la norma es el siguiente: "Dos o más accionistas que no sean administradores de la sociedad, podrán celebrar acuerdos en virtud de los cuales se comprometan a votar en igual o determinado sentido en las asambleas de accionistas. Dicho acuerdo podrá comprender la estipulación que permita a uno o más de ellos o a un tercero, llevar la representación de todos en la reunión o reuniones de la asamblea. Esta estipulación producirá efectos respecto de la sociedad siempre que el acuerdo conste por escrito y que se entregue al representante legal para su depósito en las oficinas donde funcione la administración de la sociedad. En lo demás, ni la sociedad ni los demás accionistas responderán por el incumplimiento a los términos del acuerdo”. Colombia, Ley 222 de 1995, por la cual se modifica el Libro II del Código de Comercio, se expide un nuevo régimen de procesos concursales y se dictan otras disposiciones, 42.156 Diario Oficial, 20 de diciembre de 1995. Disponible en: http://www.secretariasenado.gov.co/senado/basedoc/ley_0222_1995.html 


\section{A. La limitación a la sociedad anónima y su eventual extensión a otros tipos societarios}

La Ley 222 de 1995, entre otros aspectos, introdujo algunas reglas especiales sobre la sociedad anónima en el capítulo VII, que comprende los artículos 49 a 70, norma esta última que se refiere a los acuerdos entre accionistas ${ }^{8}$. Esto permite destacar que el alcance material de los pactos de accionistas, conforme a lo establecido en el artículo 70 de la Ley 222, está restringido a las sociedades anónimas, como quiera que el legislador no lo contempló de manera amplia para otros tipos societarios.

Ahora, aunque sin decirlo expresamente, al parecer la Superintendencia de Sociedades ha conceptuado que considera viables los pactos de socios en los demás tipos societarios distintos a las sociedades por acciones 9 .

Tal conclusión también se desprende del mismo párrafo cuando señala que "...lo que entre otras implica que el acuerdo exclusivamente podrá versar sobre la forma en que habrá de emitirse el voto en las reuniones del máximo órgano social, o referirse a la persona o personas que representarán el bloque de acciones, cuotas o partes de interés de los participantes en una o varias reuniones del mencionado órgano"10. Esta es la lectura que de este concepto citado hacen José Ignacio Narváez-García y Olga Stella Narváez-Bonnet, al afirmar: “...suscita curiosidad el Oficio 220-9238 del 11 de marzo del 2004 en el que la Superintendencia de Sociedades hace extensiva su aplicación a tipos de sociedades distintos de las por acciones"11.

8 Francisco Reyes-Villamizar, Evolución del derecho comercial. Cincuenta años de transformaciones, en Estudios de derecho económico. Tomo I. Instituciones de derecho comercial, 69-98, 79 (José Alpiniano García-Muñoz \& Jorge Oviedo-Albán, coords., Ediciones Jurídicas Gustavo Ibáñez, Bogotá, 2003).

9 En efecto, en oficio 220-009238 de 11 de marzo de 2004, la Superintendencia señaló que “...la norma transcrita permite que dos o más socios o accionistas que no sean administradores de la sociedad, celebren un acuerdo, cuyas estipulaciones también resultarán vinculantes para la sociedad y para los restantes asociados...". Colombia, Superintendencia de Sociedades, Oficio 220-009238, 11 de marzo de 2004. Disponible en: http://www.supersociedades.gov.co/superintendencia/normatividad/ conceptos/conceptos-juridicos/Normatividad\%20Conceptos\%20Juridicos/14309.pdf

10 Colombia, Superintendencia de Sociedades, Oficio 220-009238, 11 de marzo de 2004.

11 José Ignacio Narváez-García \& Olga Stella Narváez-Bonnet, Régimen legal de las sociedades, 245 (Legis, Bogotá, 2016). Oviedo también se pronuncia destacando la extensión a otros tipos societarios por medio del oficio citado. Jorge Oviedo-Albán, Flexibilización de la constitución de sociedades en Colombia, en Modernización del derecho societario, 59-82, 76, nota 33 (MARÍA Fernanda Vásquez-Palma \& José Miguel Embid-Irujo, dirs., Thomson Reuters, Santiago, 2015). Cabe añadir que también en el oficio 220-025702, la Superintendencia de Sociedades se manifestó 
También debe considerarse, como lo hace Francisco ReyesVillamizar, la posibilidad de extender la regulación de los pactos de accionistas a otros tipos societarios, concretamente a las sociedades de responsabilidad limitada, teniendo en cuenta lo establecido en el artículo 372 del Código de Comercio, norma según la cual, en lo no previsto en el respectivo título $\mathrm{V}$, que regula la sociedad de responsabilidad limitada, estas se regirán por las disposiciones sobre sociedades anónimas ${ }^{12}$.

Además de lo anterior, e independientemente de la postura que se asumirá más adelante en este trabajo, como la posibilidad de admitir la viabilidad de los pactos de socios en todos los tipos societarios, cabe anotar que la posición asumida por la Superintendencia de Sociedades puede tener fundamento jurídico en el derecho colombiano por vía de la aplicación analógica del artículo 70 del Código de Comercio, bajo el entendido de que las normas sobre los distintos tipos societarios no contemplan disposición alguna que regule los pactos de socios, sin que se encuentre ninguna restricción para ello.

Antes al contrario, la posibilidad de aplicación analógica de las normas comerciales es un recurso de integración normativa contemplado en el propio Código de Comercio en su artículo $1^{13}$.

también a favor de aplicar los pactos de socios del artículo 70 de la Ley 222 de 1995, a otros tipos societarios. Así, al explicar el alcance de este pacto y del contenido en el artículo 24 de la Ley 1258 de 2008, manifestó: "Ubicados en el escenario anterior, tenemos que en ambas disposiciones legales, encontramos los denominados ACUERDOS ENTRE ACCIONISTAS, viables ambos dentro de una normatividad exclusiva, con particularidades que le son propias, aplicable por un lado a los diversos tipos societarios regulados por el Código de Comercio y la Ley 222 citada...". Colombia, Superintendencia de Sociedades, Oficio 220-025702, 29 de abril de 2010. Disponible en: http:// www.supersociedades.gov.co/superintendencia/normatividad/conceptos/conceptos-juridicos/ Normatividad\%20Conceptos\%20Juridicos/30575.pdf

12 Francisco Reyes-Villamizar, Derecho societario, I, 641, nota 198 (3 ${ }^{\mathrm{a}}$ ed., Temis, Bogotá, 2016). En la doctrina española, Cándido Paz-Ares ha afirmado (y esto aplica también al caso colombiano) que las normas específicas de “...la organización de la sociedad anónima o limitada no constituyen límite alguno para la autonomía privada en el campo parasocial, puesto que esta no afecta a la estructura de la organización puesta en pie, sino solo a las relaciones entre sus miembros”. CÁNDIDO PAZ-ARES, La cuestión de la validez de los pactos parasociales, Número especial Actualidad jurídica Uría Menéndez. Homenaje al profesor D. Juan Luis Iglesias-Prada, 252-256, 254 (2011). Disponible en: http://www.uria.com/documentos/publicaciones/3216/documento/art32.pdf?id=3361

13 La norma dispone: "Los comerciantes y los asuntos mercantiles se regirán por las disposiciones de la ley comercial, y los casos no regulados expresamente en ella serán decididos por analogía de sus normas". Colombia, Decreto 410 de 1971, por el cual se expide el Código de Comercio, 33.339 Diario Oficial, 16 de junio de 1971. Disponible en: http:/www.secretariasenado.gov.co/senado/ basedoc/codigo_comercio.html 
Además de ello, también el artículo 8 de la Ley 153 de 1887 contempló tal posibilidad ${ }^{14}$.

\section{B. La restricción subjetiva y la sanción por su violación}

En segundo lugar, debe destacarse su limitación subjetiva, toda vez que restringe su participación a los accionistas que no sean administradores de la sociedad ${ }^{15}$. Además, según lo conceptuado por la Superintendencia de Sociedades en el oficio 220-17650, se trata de un requisito que no admite excepciones. En efecto, la Superintendencia ha dicho en el oficio mencionado: “...en ningún caso un administrador que a su vez sea accionista de la sociedad, puede formar parte de un acuerdo entre accionistas o de sindicato de accionistas" $"$.

De todos modos, esta concepción se encuentra frente a una postura doctrinal distinta, según la cual cuando se trata de acuerdos no oponibles, que como se verá son los que no cumplen el requisito de

14 "Cuando no haya ley exactamente aplicable al caso controvertido, se aplicarán las leyes que regulen casos o materias semejantes...”. Colombia, Ley 153 de 1887, que adiciona y reforma los códigos nacionales, la ley 61 de 1886 y la 57 de 1887, 7.151 Diario Oficial, 28 de agosto de 1887, artículo 8. Disponible en: http://suin-juriscol.gov.co/viewDocument.asp?id=1792950. Este argumento, basado en el artículo 8 de la Ley 153 de 1887, es también sostenido por Francisco ReYes-VilLamizar, Derecho societario, I, 641, nota 108 ( $3^{\mathrm{a}}$ ed., Temis, Bogotá, 2016). En relación con la analogía prevista en el artículo 1 del Código de Comercio: GABINo PInZÓn, Introducción al derecho comercial, 87 ( $3^{\mathrm{a}}$ ed., Temis, Bogotá, 1985). Véase también sobre este punto: Ramón MAdriñán DE LA TorRE \& Yolima Prada-Márquez, Principios de derecho comercial, 47 (11 a ed., Temis, Bogotá, 2013). José Ignacio Narváez-García, Derecho mercantil colombiano. Parte general, 110-112 (9ª ed., Legis, Bogotá, 2002). Carlos Alberto Velásquez-Restrepo, Instituciones de derecho comercial, 84 ( $5^{\mathrm{a}}$ ed., Señal Editora, Medellín, 2008). Sobre el particular, véanse también los planteamientos de Leonardo Espinosa-Quintero, quien sostiene la posibilidad de acudir a una analogía interna, es decir, de las propias normas mercantiles, que es la prevista en el propio artículo 1 del Código de Comercio, y una “externa", la que permitiría — según lo dispuesto en el artículo 8 de la Ley 153 de 1887- acudir a la analogía de otras normas que traten temas o materias semejantes. Ello, independientemente de la aplicación por remisión "directa" que el propio Código de Comercio hace hacia otras disposiciones, como es el caso de las reglas sobre capacidad o las de obligaciones y contratos o de capacidad, según lo dispuesto en el artículo 11 y el 822 del mismo Código. El autor califica estos tres fenómenos como manifestación de la "interpretación extensiva" de las normas. LeOnARDo EsPinOsA-Quintero, Introducción al derecho mercantil, 94 (Universidad Sergio Arboleda, Bogotá, 2008).

15 Para estos efectos, téngase en cuenta el concepto de "administradores" contenido en el artículo 22 de la Ley 222 de 1995, conforme al cual: "Son administradores, el representante legal, el liquidador, el factor, los miembros de juntas o consejos directivos y quienes de acuerdo con los estatutos ejerzan o detenten esas funciones". En este mismo sentido lo advierte Francisco Reyes-Villamizar, Derecho societario, I, 641, nota 108 ( $3^{\text {a }}$ ed., Temis, Bogotá, 2016).

16 Colombia, Superintendencia de Sociedades, Oficio 220-17650, 18 de abril de 2002. Disponible en http://www.supersociedades.gov.co/superintendencia/normatividad/conceptos/conceptos-juridicos/ Normatividad\%20Conceptos\%20Juridicos/4369.pdf 
publicidad establecido en el artículo 70 de la Ley 222, es decir, que por ende no quedan regulados por tal disposición sino más bien por la regla del artículo 118 del Código de Comercio, de tal manera que los socios no administradores, sí podrían celebrar tales pactos ${ }^{17}$.

Aunque en principio se infiere de ello (y además por la estructura y dimensiones de la sociedad anónima), que los accionistas no tengan participación en los órganos de dirección, salvo obviamente en la Asamblea General de Accionistas, nada impide que puedan participar en ellos. De esta manera, si alguno o algunos de los accionistas llegaren entonces a ostentar tales cargos, no pueden ser parte de los acuerdos de accionistas previstos en el artículo 70 de la Ley 222.

Ahora bien, cabe meditar sobre el alcance de tal prohibición y los efectos de su violación. Por los términos utilizados por el artículo 70, se infiere que los accionistas que no sean administradores pueden celebrar tales pactos y al contrario, quienes sean administradores no pueden hacerlo. Se trata entonces de una especie de prohibición para los administradores. En cuanto a la sanción por violar tal prohibición, bien podría pensarse que se genera nulidad absoluta del acuerdo, al menos para el o los accionistas que ostentando tal calidad lo hubiesen celebrado.

Para estos efectos, téngase en cuenta tanto lo dispuesto en el artículo 899 del Código de Comercio, que en su numeral 2 establece como causal de nulidad absoluta, la causa u objeto ilícito del negocio jurídico, como el artículo 1523 del Código Civil, según el cual hay objeto ilícito en todo contrato prohibido por las leyes. De hecho, así lo ha entendido la Superintendencia de Sociedades en oficio 220-071798 de 17 de julio de 2005, en el que sostuvo que la violación de este requisito "...trae como resultado que el acuerdo de votación esté viciado de nulidad absoluta, tanto por violar una norma imperativa (artículo 70 Ley 222 de 1995), como por desconocer la prohibición de ejecutar actos expresamente prohibidos por la ley (artículos 899 numeral 1 C. Co. y 1504 inciso final C.C.)"18.

17 Francisco Reyes-Villamizar, Derecho societario, I, 641 ( $3^{\mathrm{a}}$ ed., Temis, Bogotá, 2016). Ana María Correa-GonzÁlez, Los acuerdos de accionistas bajo la Ley 1258 de 2008, 12 (Pontificia Universidad Javeriana, Bogotá, 2011).

18 Colombia, Superintendencia de Sociedades, Oficio 220-071798, 17 de julio de 2005. Doctrinas jurídicas y contables 1994-2009, 10-14, 11 (Superintendencia de Sociedades, Bogotá, 2009). 
De todas maneras, cabe sostener que la nulidad que se produce es relativa, puesto que se trata de una prohibición consagrada en la ley a partir de la calidad o estado de las personas que los ejecutan o acuerdan y, según lo establecido en el artículo 1741 del Código Civil, esta es causal de nulidad relativa del acto ${ }^{19}$. Además, se puede afirmar que puede tratarse de una nulidad parcial del pacto en relación con el vínculo del accionista o accionistas sobre quienes recaiga tal prohibición, todo en los términos del artículo 902 de Código de Comercio.

Un aspecto adicional que la ley no regula es el caso en que alguno o algunos de los accionistas no hubieren estado inmersos en la prohibición al momento de celebrar el pacto, pero con posterioridad al mismo llegaren a ostentar la calidad de administradores. Se trata de una situación constitutiva de lo que alguna doctrina denomina "nulidad sucesiva" para referirse a eventos en los que al momento de celebrarse el contrato, se cumplen los requisitos de validez, pero durante su ejecución, ocurre una circunstancia constitutiva de causal de nulidad ${ }^{20}$. Para Arturo Alessandri-Besa, el efecto que se genera es la nulidad del contrato, como en los casos en que este hubiese sido nulo desde el principio ${ }^{21}$. De todas formas, en la doc-

19 Esta posición ha sido asumida en la doctrina chilena por Luis Claro-Solar. Según el autor, al comentar el alcance del inciso final del artículo 1447 del Código Civil chileno, equivalente al inciso final del artículo 1504 del Código Civil colombiano, que establece: “Además de estas incapacidades hay otras particulares que consisten en la prohibición que la ley ha impuesto a ciertas personas para ejecutar estos actos", la expresión "prohibición” empleada por esta disposición, no se utiliza en el sentido de tratarse de un acto prohibido por la ley, que por ello tendría objeto ilícito y sería causa de nulidad absoluta, sino que a pesar de ser un contrato válido y celebrado por una persona capaz, no puede ser ejecutado por ella. Además, se basa en el artículo 1682 del Código chileno, equivalente al 1741 del Código colombiano, para sostener que según la norma, la inobservancia de requisitos consagrados en la ley en atención a la calidad o estado de quienes ejecutan o acuerdan los respectivos actos, es causal de nulidad relativa. Luis Claro-Solar, Explicaciones de derecho civil chileno y comparado, Tomo 11, De las obligaciones, II, 46 (Nascimento, Santiago, 1937). En Colombia, Ospina y Ospina han sostenido la tesis según la cual, en cada caso, hay que verificar cuáles fueron los motivos que llevaron al legislador a establecer la prohibición para que ciertas personas celebren determinados actos. Así, según los autores, si hay motivos de orden público, se impone la sanción de nulidad absoluta conforme al artículo 1523 del Código Civil. Guillermo Ospina-Fernández \& Eduardo Ospina-Acosta, Teoría general del contrato y del negocio jurídico, 97 ( $7^{\mathrm{a}}$ ed., $4^{\mathrm{a}}$ reimp., Temis, Bogotá, 2016). También Jorge Cubides-Camacho, al referirse al artículo 1504 del Código Civil, afirma que las inhabilidades especiales, como las denomina, generan nulidad relativa. JORGE Cubides-Camacho, Obligaciones, 217 ( $8^{\mathrm{a}}$ ed., Pontificia Universidad Javeriana, Ibáñez, Bogotá, 2017).

20 Arturo Alessandri-Besa, La nulidad y la rescisión en el derecho civil chileno, tomo 1, 116 (3ª ed., JORGE WAHL, actual., Editorial Jurídica de Chile, Santiago, 2008).

21 Arturo Alessandri-Besa, La nulidad y la rescisión en el derecho civil chileno, tomo 1, 116 ( ${ }^{\mathrm{a}}$ ed., JoRge WAHL, actual., Editorial Jurídica de Chile, Santiago, 2008). 
trina chilena se encuentra también una posición distinta que resulta más adecuada: la sostenida por Ramón Domínguez-Águila, según la cual la nulidad es una sanción a un vicio originario de tal forma que la misma debe existir al momento de celebrarse el negocio de modo que si esta se produce durante la vida del contrato, no puede hablarse propiamente de una nulidad sino que deberá buscarse otra sanción, como pudiera ser eventualmente la resolución ${ }^{22}$.

También en Colombia se ha pronunciado en este sentido Fernando Hinestrosa-Forero, para quien la nulidad sobreviniente no significa que el contrato devenga inválido, sino que sus efectos (los que estuvieren pendientes) no pueden producir efectos, o bien dejará de producirlos ${ }^{23}$. De esta forma entonces, lo que puede sostenerse es que para tales accionistas que con posterioridad al pacto llegaren a ostentar la calidad de administradores de la sociedad, el pacto dejaría de producir efectos, y solo los recobraría cuando dejen de tener tal calidad.

\section{El alcance objetivo del acuerdo}

Otro aspecto que debe considerarse es el relativo al ámbito objetivo de aplicación del pacto de accionistas, según lo contemplado en el artículo 70 de la Ley 222 de 1995.

De la propia redacción de la norma se infiere que la modalidad de acuerdo de accionistas prevista en el mencionado artículo 70, es la conocida como "acuerdo de voto", en virtud de los cuales los socios o accionistas acuerdan la forma de regular los derechos y obligaciones resultantes de su estado de socio, de tal manera que se comprometen a votar en un determinado sentido en las reuniones de los órganos de decisión, como las juntas de socios o asambleas de accionistas ${ }^{24}$. En efecto, la norma establece con claridad que: "Dos o más accionistas que no sean administradores de la sociedad

22 Ramón Domínguez-Águila, Teoría general del negocio jurídico, 186 ( $2^{\mathrm{a}}$ ed., Editorial Jurídica de Chile, Santiago, 2012).

23 Fernando Hinestrosa-Forero, Tratado de las obligaciones II. De las fuentes de las obligaciones: el negocio jurídico, volumen II, 734 (Universidad Externado de Colombia, Bogotá, 2015).

24 PABlo ANDRÉs CóRDoBA-Acosta, El derecho de sociedades y el gobierno de la sociedad anónima: el interés social, órganos, accionistas y administradores, 520 (Universidad Externado de Colombia, Bogotá, 2014). Francisco Reyes-Villamizar, Derecho societario en Estados Unidos y la Unión Europea, 259-260 (4 ed., Legis, Bogotá, 2013). Alfredo L. Rovira, Pactos de socios, 1, 97 (Astrea, Buenos Aires, 2006). 
podrán celebrar acuerdos en virtud de los cuales se comprometen a votar en igual o determinado sentido en las asambleas de accionistas. Dicho acuerdo podrá comprender la estipulación que permita a uno o más de ellos o a un tercero, llevar la representación de todos en la reunión o reuniones de la asamblea (...)".

De esta manera, entonces, el alcance de tales acuerdos es doble: se refieren en primer lugar al pacto encaminado a votar en igual o determinado sentido en la asamblea y también, a la posibilidad de que uno de ellos represente a los otros en las reuniones del máximo órgano social. Debe tenerse en cuenta, y como lo ha conceptuado la Superintendencia de Sociedades en el oficio 220-003037, que este acuerdo no se limita solamente a admitir la representación contemplada en el artículo 184 del Código de Comercio, modificado por el artículo 18 de la Ley 222 de 1995, norma conforme a la cual todo socio puede hacerse representar en las reuniones de la junta de socios o asamblea mediante poder escrito otorgado a un representante ${ }^{25}$.

Sin haber claridad sobre cuáles pudieron ser las razones que llevaron al legislador a restringir objetivamente el alcance del pacto de accionistas, puede sostenerse que ello no significa que otras modalidades del mismo estén prohibidas o que no puedan celebrarse acuerdos sobre asuntos diversos ${ }^{26}$. Se trataría de un mero silencio de la ley ante el cual no se ve objeción alguna para que las partes puedan pactar cualquier objeto lícito y que además no contravenga lo establecido en los estatutos societarios. En este sentido se ha pronunciado la Superintendencia de Sociedades en el oficio 220-17650, al señalar que: "En el artículo 70 de la ley 222, solo se consagra el denominado sindicato de voto, sin que ello sea

25 Colombia, Superintendencia de Sociedades, Oficio 220-003037, 6 de enero de 2012. Disponible en: http://www.supersociedades.gov.co/superintendencia/normatividad/conceptos/conceptos-juridicos/ Normatividad\%20Conceptos\%20Juridicos/32065.pdf. En efecto, según la Superintendencia ha dicho: “...el objeto de un acuerdo va más allá de la simple representación de que trata el artículo 184 del Código de Comercio, para lo cual solo se requiere de un poder o autorización por escrito otorgado por los socios o accionistas, en el que se indique el nombre del apoderado, la fecha o época de la reunión o reuniones para las que se confiere, y demás requisitos que señalen los estatutos, la representación en el caso que se analiza es accesoria, lo realmente importante son los asuntos que comprende o finalidad del acuerdo que se suscribe siempre relacionado con el voto en asuntos propios del máximo órgano social, que es lo que contempla el artículo 70 cit.".

26 Francisco Reyes-Villamizar, Derecho societario, I, 643 ( $3^{\mathrm{a}}$ ed., Temis, Bogotá, 2016). PAblo Andrés CórdoBA-Acosta, El derecho de sociedades y el gobierno de la sociedad anónima: el interés social, órganos, accionistas y administradores, 520 (Universidad Externado de Colombia, Bogotá, 2014). 
impedimento alguno para que en ejercicio de la voluntad privada, se proceda a conformar otra clase de sindicatos" 27 .

Ahora, cabe advertir como lo hace Reyes-Villamizar, que acuerdos que versen sobre otros aspectos distintos de los contemplados en el artículo 70 no obstante ser válidos, no vinculan a la sociedad ni a los demás asociados ${ }^{28}$. En el mismo sentido, Néstor Humberto Martínez-Neira, al afirmar que en consecuencia, tales pactos seguirán regidos por el artículo 118 del Código de Comercio ${ }^{29}$.

Esta posición doctrinal es también la que ha adoptado la Superintendencia de Sociedades en el oficio 220-009238, 11 de marzo de 2004, al señalar que se debe "...concluir categóricamente que no es viable al amparo del artículo 70 de la mencionada Ley 222, celebrar acuerdos sobre temas distintos a los señalados taxativamente, se debe precisar en todo caso, que ello no obsta para que los asociados en ejercicio de la autonomía de la voluntad privada, puedan celebrar discrecionalmente acuerdos sobre otros asuntos, como serían los que contengan condiciones relacionadas con la enajenación de acciones, caso en el cual estos, que la doctrina ha denominado tradicionalmente acuerdos privados, resultarán plenamente válidos entre los socios que los suscriben, pero a diferencia de los anteriores, no tendrán carácter vinculante frente a la compañia ni a los demás asociados (artículo 118 del Código de Comercio)" ${ }^{\prime 30}$.

\section{Los requisitos de forma}

Adicionalmente, la norma consagra dos requisitos para que el pacto produzca efectos frente a la sociedad: que conste por escrito y que

27 Colombia, Superintendencia de Sociedades, Oficio 220-17650, 18 de abril de 2002. Disponible en http://www.supersociedades.gov.co/superintendencia/normatividad/conceptos/conceptos-juridicos/ Normatividad\%20Conceptos\%20Juridicos/4369.pdf. De igual forma, se manifestó la Superintendencia en el oficio 220-071798. Colombia, Superintendencia de Sociedades, Oficio 220-071798, 17 de julio de 2005. Doctrinas jurídicas y contables 1994-2009, 10-14, 12 (Superintendencia de Sociedades, Bogotá, 2009).

28 Francisco Reyes-Villamizar, Derecho societario, I, 644 (3 ${ }^{\mathrm{a}}$ ed., Temis, Bogotá, 2016).

29 Néstor Humberto Martínez-Neira, Cátedra de derecho contractual societario Regulación comercial y bursátil de los contratos societarios, 139 (2ª ed., Legis, Bogotá, 2014). Igualmente es lo que sostiene Ana María Correa-GonzÁlez, Los acuerdos de accionistas bajo la Ley 1258 de 2008, 14 (Pontificia Universidad Javeriana, Bogotá, 2011).

30 Colombia, Superintendencia de Sociedades, Oficio 220-009238, 11 de marzo de 2004. Tal posición ha sido reiterada en: Colombia, Superintendencia de Sociedades, Oficio 220-059299, 17 de diciembre de 2007. Disponible en: http:/www.supersociedades.gov.co/superintendencia/normatividad/conceptos/ conceptos-juridicos/Normatividad\%20Conceptos\%20Juridicos/28212.pdf. Colombia, Superintendencia de Sociedades, Oficio 220-000283, 5 de enero de 2016. Disponible en: http://www.super sociedades.gov.co/superintendencia/normatividad/conceptos/conceptos-juridicos/Normatividad \%20Conceptos\%20Juridicos/OFICIO\%20220-000283.pdf. Colombia, Superintendencia de Sociedades, Oficio 220-246524, 16 de diciembre de 2016. Disponible en: http://bibliotecadigital.ccb. org.co/bitstream/handle/11520/18528/SuperSociedades-Concepto-2016-N0246524_20161216\%20 
se entregue al representante legal para su depósito en las oficinas donde funcione la administración de la sociedad. Se infiere que se trata de un requisito de publicidad del pacto, y no una solemnidad exigida para su perfeccionamiento que, de no cumplirse, lo haría inoponible ante la sociedad ${ }^{31}$.

Por su parte, la Ley 964 de 2005, en su artículo 43, se encargó también de regular algunos aspectos relativos a la publicidad de los acuerdos entre accionistas, según pasa a explicarse ${ }^{32}$.

Como puede advertirse, esta regla introduce un requisito adicional para los pactos de accionistas de ciertas sociedades - como las anónimas que tengan acciones o bonos obligatoriamente convertibles en acciones-, que estén inscritos en el Registro Nacional de Valores y Emisores, RNVE, según lo establecido en el artículo 38 de esa ley ${ }^{33}$. También, a diferencia del artículo 70 de la Ley 222,

(1) $\% 20$ todas.pdf?sequence $=1$

31 Francisco Reyes-Villamizar, Derecho societario, I, 644 ( $3^{\text {a }}$ ed., Temis, Bogotá, 2016).

32 Según el título de la Ley 964 de 2005, mediante ella se dictaron normas y se señalaron objetivos y criterios "a los cuales debe sujetarse el Gobierno Nacional para regular las actividades de manejo, aprovechamiento e inversión de recursos captados del púbico que se efectúen mediante valores y se dictan otras disposiciones". El texto de la norma es el siguiente: "Artículo 43. Acuerdos entre accionistas. Los acuerdos entre accionistas de sociedades inscritas deberán, además de cumplir con los requisitos previstos en el artículo 70 de la Ley 222 de 1995, divulgarse al mercado, inmediatamente sean suscritos, a través del Registro Nacional de Valores y Emisores.

Sin el lleno de los requisitos a que se refiere la presente norma los acuerdos de accionistas no producirán ningún tipo de efectos entre las partes, frente a la sociedad, frente a los demás socios o frente a terceros

Parágrafo 1. Excepcionalmente, la Superintendencia de Valores podrá autorizar la no divulgación de un acuerdo de accionistas, cuando así estos lo soliciten y demuestren sumariamente que la inmediata divulgación del mismo les ocasionaría perjuicios. En ningún caso podrá permanecer sin divulgación un acuerdo de esta naturaleza durante un término superior a doce (12) meses, contados a partir de su celebración.

Parágrafo 2. Los acuerdos entre accionistas que se hayan suscrito con anterioridad a la vigencia de la presente ley deberán registrarse en el Registro Nacional de Valores y Emisores dentro de los tres (3) meses siguientes a la entrada en vigencia de la misma. Aquellos acuerdos entre accionistas que no se registren en los términos anteriores no producirán efectos a partir del vencimiento del plazo de tres (3) meses fijado en el presente parágrafo". Colombia, Ley 964 de 2005, por la cual se dictan normas generales y se señalan en ellas los objetivos y criterios a los cuales debe sujetarse el Gobierno Nacional para regular las actividades de manejo, aprovechamiento e inversión de recursos captados del público que se efectúen mediante valores y se dictan otras disposiciones, 45.963 Diario Oficial, 8 de julio de 2005. Disponible en: http://www.secretariasenado.gov.co/senado/basedoc/ ley_0964_2005.html

Debe tenerse en cuenta que las funciones de la antigua Superintendencia de Valores, a partir de la fusión con la Superintendencia Bancaria, fueron asumidas por la Superintendencia Financiera de Colombia, según lo establece el artículo 1 del Decreto 4327 de 2005. Colombia, Decreto 4327 de 2005, por el cual se fusiona la Superintendencia Bancaria de Colombia en la Superintendencia de Valores y se modifica su estructura, 46.104 Diario Oficial, 26 de noviembre de 2005. Disponible en: http://www.secretariasenado.gov.co/senado/basedoc/decreto_4327_2005.html

33 "El Registro Nacional de Valores y Emisores, RNVE, tiene por objeto inscribir las clases y tipos de valores, así como los emisores de los mismos y las emisiones que estos efectúen, y certificar lo 
se encarga de señalar el efecto derivado del no cumplimiento del requisito de publicidad, que es la ineficacia del pacto. De esta manera, entonces, al parecer tal requisito va más allá de ser una simple exigencia de forma o publicidad, cuya inobservancia debiera ser la inoponibilidad del pacto y se convierte en un requisito exigido para su eficacia.

\section{E. La duración del acuerdo}

La Ley 222 nada establece en relación con la duración del acuerdo. Sobre esto, cabe entonces asumir que el mismo podría contener una cláusula que fije su término de duración. Ahora, en el evento en que nada se hubiere pactado sobre su duración, puede entenderse que es indefinido, hasta que recaiga sobre él una causa extintiva de las obligaciones $^{34}$. También en concepto 220-30490, la Superintendencia de Sociedades ha afirmado que, si en el acuerdo nada se pactó en cuanto a su duración, “...este regirá en todas aquellas ocasiones en que se traten los temas incluidos en el mismo o siempre que se reúna el máximo órgano social si estos no fueron especificados, y por término indefinido, considerando que la norma no consagra límites acerca de la duración de los acuerdos entre accionistas" 35 .

\section{F. El incumplimiento del acuerdo}

En cuanto al incumplimiento de lo convenido en el pacto, se debe hacer referencia en primer lugar al significado de la parte final del artículo 70 de la Ley 222 de 1995 que dispone: "En los demás, ni la sociedad ni los demás accionistas responderán por el incumplimiento a los términos del acuerdo". Esta disposición, según Francisco Reyes-Villamizar, no debe entenderse como que la sociedad o los demás asociados que no hubieren intervenido en el pacto no están

relacionado con la inscripción de dichos emisores clases y tipos de valores. La inscripción en este registro es requisito para aquellas entidades que deseen realizar una oferta pública de sus valores o que los mismos se negocien en un sistema de negociación”. Información tomada de: https://www. superfinanciera.gov.co

34 Néstor Humberto Martínez-Neira, Cátedra de derecho contractual societario, Regulación comercial y bursátil de los contratos societarios, 142 ( $2^{\text {a }}$ ed., Legis, Bogotá, 2014).

35 Colombia, Superintendencia de Sociedades, Concepto 220-30490, 1 de julio de 2004. Disponible en: http://www.supersociedades.gov.co/superintendencia/normatividad/conceptos/conceptos-juridicos/ Normatividad\%20Conceptos\%20Juridicos/15632.pdf 
obligados a respetar el acuerdo ${ }^{36}$. Una interpretación de ese estilo haría inútil la celebración del pacto y también de nada valdría el cumplimiento del requisito de publicidad ya mencionado. Como bien explica el autor citado, la propia disposición normativa señala que al cumplirse tales requisitos de forma y publicidad, el pacto producirá efectos respecto de la sociedad, por lo que la sociedad debe respetarlo ${ }^{37}$. Por eso, es correcta la interpretación que ofrece el autor, al considerar que la frase "...ni la sociedad ni los demás accionistas responderán por el incumplimiento a los términos del acuerdo", se refiere a los eventuales perjuicios entre quienes hubieren suscrito el pacto que se deriven de un incumplimiento del mismo, los cuales no corresponderá asumir ni a la sociedad ni a los demás asociados, sino directamente a los socios parte del mismo que lo hubiesen incumplido ${ }^{38}$.

Por otra parte, cabe mencionar aquí la postura asumida por la Superintendencia de Sociedades al decidir en el caso Proedinsa Calle \& Cía. S. en C., contra Inversiones Vermont Uno S. en C., y otros, en relación con los efectos del acuerdo de accionistas y su inobservancia ${ }^{39}$.

La pretensión entablada por el demandante se refirió al incumplimiento de un acuerdo celebrado entre los accionistas de una sociedad, de forma que por ello no debía reconocerse valor ni efectos jurídicos a los actos celebrados y ejecutados contrariando lo estipulado en el mismo, como era el caso de una reforma de estatutos con aumento de capital autorizado, reglamento de colocación y venta de acciones. En tal acuerdo se habían estipulado las reglas para el funcionamiento de los órganos sociales, como la junta directiva, y también los funcionarios que esta fuere a nombrar, los cuales debían haber sido concertados de manera previa por los accionistas. Además, se incluía una cláusula sobre capitalización futura de la sociedad, la cual debía ser discutida fuera de la asamblea de accio-

36 Francisco Reyes-Villamizar, Derecho societario, I, 646 ( $3^{\mathrm{a}}$ ed., Temis, Bogotá, 2016).

37 Francisco Reyes-Villamizar, Derecho societario, I, 647 ( $3^{\mathrm{a}}$ ed., Temis, Bogotá, 2016).

38 Francisco Reyes-Villamizar, Derecho societario, I, 648 (3ª ed., Temis, Bogotá, 2016).

39 Colombia, Superintendencia de Sociedades, Proedinsa Calle \& Cía. S. en C., contra Inversiones Vermont Uno S. en C., Inversiones Vermont Dos S. en C., Inversiones Vermont Tres $S$. en C., y Colegio Gimnasio Vermont Medellín S.A., Sentencia 801-016, 23 de abril de 2013, Jurisprudencia societaria, 229-254 (Superintendencia de Sociedades, Bogotá, 2014). Disponible en: http://www.super sociedades.gov.co/procedimientos-mercantiles/la-delegatura/jurisdiccion-societaria/jurisprudencia/ Documents/Libro\%20Jurisprudencia\%20societaria.pdf 
nistas, a fin de aprobar eventuales capitalizaciones solo en caso de presentarse consenso entre los socios.

La asamblea general de accionistas aprobó una reforma de estatutos con el fin de aumentar el capital autorizado, mediante decisión que fue votada en contra por un bloque de accionistas minoritarios. Además de ello, en la junta directiva fue aprobado un reglamento de emisión y colocación de acciones. La Superintendencia de Sociedades declaró incumplido el acuerdo de voto, de tal forma que decidió descontar los votos emitidos por los accionistas mayoritarios del cómputo que se efectuó al aprobar el aumento de capital autorizado, procedió a declarar nula absolutamente la decisión de reforma de los estatutos para el aumento del capital y también dejó sin efecto el reglamento de emisión y colocación de acciones.

En sus consideraciones, la Superintendencia hizo una serie de planteamientos relacionados con la finalidad y las funciones de los acuerdos societarios, y señaló que estos buscan satisfacer necesidades de contenido económico, además de servir de “...aliciente para efectuar inversiones en sociedades de capital, en la medida en que le confieren solidez a los compromisos adquiridos ex ante por los asociados. Para estos efectos, una de las funciones más importantes de los acuerdos privados está relacionada con la configuración de las relaciones entre los accionistas de una compañía"40. Además, señaló claramente que tales acuerdos, al cumplir con los requisitos formales y de publicidad producen efectos respecto de la sociedad, configurándose de esta forma en una excepción al principio de relatividad de los actos jurídicos.

De igual forma, se pronunció en relación con el cumplimiento del pacto, al sostener que la obligatoriedad de tales acuerdos se funda en los postulados del derecho de obligaciones y contratos contenidos en las reglas comunes, lo que sirve de fundamento sin duda para afirmar que el régimen aplicable a los pactos de socios está contenido no solamente en las normas societarias que los tipifican, como el artículo 70 de la Ley 222 de 1995, sino también en las reglas generales aplicables a las obligaciones y contratos

40 Colombia, Superintendencia de Sociedades, Proedinsa Calle \& Cía. S. en C., contra Inversiones Vermont Uno $S$. en C., Inversiones Vermont Dos $S$. en $C$., Inversiones Vermont Tres $S$. en $C$., y Colegio Gimnasio Vermont Medellín S.A., Sentencia 801-016, 23 de abril de 2013, Jurisprudencia societaria, 229-254, 236-237 (Superintendencia de Sociedades, Bogotá, 2014). 
contenidas tanto en el Código de Comercio como en el Código Civil14. Así dijo la Superintendencia: "Por lo demás, es necesario llamar la atención sobre la importancia que reviste asegurar el estricto cumplimiento de los acuerdos celebrados entre los accionistas de una compañía. Esta afirmación encuentra soporte no solo en la ya analizada función económica que cumplen esta clase de convenios, sino también en la necesidad de hacer efectivos los postulados que rigen la celebración y ejecución de contratos en Colombia, particularmente en lo que respecta al artículo 1602 del Código Civil, a cuyo tenor 'todo contrato legalmente celebrado es una ley para los contratantes, y no puede ser invalidado sino por su consentimiento mutuo o por causas legales""42.

Además, en cuanto a los efectos derivados del incumplimiento, en el fallo se señaló que bajo el derecho colombiano cabe acudir a las reglas del Código Civil sobre incumplimiento de las obligaciones de hacer y no hacer, con respecto a la ejecución judicial de los acuerdos de voto, como es el caso de las acciones contempladas en los artículos 1610 y 1612 del Código Civil ${ }^{43}$. Además de ello,

41 Cabe recordar que sobre este particular, el artículo 822 del Código de Comercio hace una remisión expresa a los principios del derecho de obligaciones del Código Civil. Sobre este particular: JAIME Alberto Arrubla-Paucar, Contratos mercantiles. Teoría general del negocio jurídico mercantil, 29-35 (13 a ed., Legis, Bogotá, 2012). Jorge Oviedo-Albán, Una vez más sobre la aplicación de las normas civiles a las obligaciones y contratos mercantiles, 25 Revista de Derecho Privado, Universidad Externado de Colombia, 81-107 (2013). Disponible en: http://revistas.uexternado.edu. co/index.php/derpri/article/view/3597/3691. En relación con la aplicación de las disposiciones del régimen de los contratos a la validez de los acuerdos de accionistas, Darío Alejandro Mejía-MejíA, Los acuerdos de accionistas. Evolución y aplicación en Colombia, 52 Revista de Derecho Privado, Universidad de los Andes, 1-30, 15 (2014).

42 Colombia, Superintendencia de Sociedades, Proedinsa Calle \& Cía. S. en C., contra Inversiones Vermont Uno S. en C., Inversiones Vermont Dos S. en C., Inversiones Vermont Tres S. en C., y Colegio Gimnasio Vermont Medellín S.A., Sentencia 801-016, 23 de abril de 2013, Jurisprudencia societaria, 229-254, 247 (Superintendencia de Sociedades, Bogotá, 2014). También en el sentido de reconocerles obligatoriedad según el artículo 1602 del Código Civil: NÉstor HumberTo MARTínezNeIRA, Cátedra de derecho contractual societario, Regulación comercial y bursátil de los contratos societarios, 134-141 ( $2^{\text {a }}$ ed., Legis, Bogotá, 2014). En la doctrina extranjera, también en ese sentido: CÁndido Paz-Ares, El enforcement de los pactos parasociales, 5 Actualidad Jurídica Uría Menéndez, 19-43, 21 (2003). Disponible en: http://www.uria.com/documentos/publicaciones/1052/ documento/03Candido.pdf

43 La Superintendencia, en concepto 220-30490, ya había afirmado lo siguiente, ante una pregunta sobre si una de las partes suscriptora de un acuerdo de accionistas puede votar en sentido contrario a lo pactado en ese acuerdo en la asamblea general de accionistas: "De conformidad con lo establecido en el artículo 1602 del Código Civil, todo contrato legalmente celebrado es una ley para los contratantes, y no puede ser invalidado sino por su consentimiento mutuo o por causas legales; en consecuencia, si una de las partes llegare a votar en sentido contrario al pactado en el acuerdo, lo estaría incumpliendo y ello le acarrearía las consecuencias propias del incumplimiento de una obligación válidamente acordada con la otra, esto es, la parte incumplida puede hacer cumplir judicialmente el compromiso y/o perseguir una indemnización de perjuicios por la inobservancia 
la Superintendencia afirmó que "...la ejecución específica de un acuerdo de voto no presupone su oponibilidad ante la sociedad", de tal manera que esta afirmación permite sostener que tratándose de los acuerdos de accionistas que no cumplan los requisitos subjetivos y objetivos, o bien con los de forma o publicidad consagrados en el artículo 70 de la Ley 222 — que son los que de alguna forma admite el artículo 118, como ya se indicó anteriormente-, no por ello quedan privados de obligatoriedad y de esta forma, bien puede acudirse entre las partes al sistema de remedios por su incumplimiento, consagrado en las normas civiles citadas.

En virtud de lo anterior, la Superintendencia sostuvo que para la ejecución específica del acuerdo, podría acudirse ante ella para que "...en una sentencia de naturaleza constitutiva, se reconozca el incumplimiento y se impartan las órdenes correspondientes"44.

cometida". Colombia, Superintendencia de Sociedades, Concepto 220-30490, 1 de julio de 2004. Disponible en: http://www.supersociedades.gov.co/superintendencia/normatividad/conceptos/ conceptos-juridicos/Normatividad\%20Conceptos\%20Juridicos/15632.pdf. En la doctrina española, Cándido Paz-Ares afirma que cualquiera de los instrumentos “...previstos en el derecho común para lograr la efectividad de la pretensión de cumplimiento resulta utilizable en el caso de los pactos parasociales sin más limitación que las generales derivadas de la imposibilidad física o jurídica de la prestación (artículo 1184 CC) o de la inexigibilidad de la misma fundada en la buena fe o en la interdicción del abuso del derecho (artículo 7 CC)...”. Cándido Paz-Ares, $E l$ enforcement de los pactos parasociales, 5 Actualidad Jurídica Uría Menéndez, 19-43, 22 (2003). También cabe sostener, como lo hace el autor desde la perspectiva del derecho español, en la posibilidad de pactar mecanismos de autotutela, como podría ser una cláusula penal, la atribución de un put o un call al incumplido para que sea obligado a adquirir las participaciones del que lo ejercita o transferir las suyas a favor de quien lo ejercita a precios "disuasorios" "...en el primer caso por encima del precio de mercado y en el segundo, por debajo". Cándido PAz-Ares, El enforcement de los pactos parasociales, 29. También en relación con la posibilidad de pactar mecanismos de autotutela para favorecer la efectividad de los pactos parasociales: Lina HenAO, Los pactos parasociales, 25 Revista de Derecho Privado, 179-217, 200 (2013).

44 Colombia, Superintendencia de Sociedades, Proedinsa Calle \& Cía. S. en C., contra Inversiones Vermont Uno S. en C., Inversiones Vermont Dos S. en C., Inversiones Vermont Tres S. en C., y Colegio Gimnasio Vermont Medellín S.A., Sentencia 801-016, 23 de abril de 2013, Jurisprudencia societaria, 229-254, 251 (Superintendencia de Sociedades, Bogotá, 2014). Sobre este punto, debe tenerse en cuenta que la Superintendencia ha establecido que para ejecutar las obligaciones contenidas en un acuerdo de accionistas, primero se debe haber declarado judicialmente el incumplimiento del pacto. Así lo sentenció en el caso de Martín Morelli Socarrás contra Santana Fruits S.A.S. Colombia, Superintendencia de Sociedades, Martín Morelli Socarrás contra Santana Fruits S.A.S. y Javier Barnier González, Sentencia 801-46, 24 de junio de 2014, Bogotá, 2014, Disponible en: http://www.super sociedades.gov.co/procedimientos-mercantiles/la-delegatura/jurisdiccion-societaria/jurisprudencia/ Documents/Ultimas\%20sentencias/Acuerdos\%20de\%20accionistas/Sentencia\%20No.\%2080146\%20\%2824-jul-2014\%29.pdf. El fallo se refirió al siguiente asunto: el demandante solicitó se declarare que respecto de los accionistas de la sociedad demandada se había celebrado un acuerdo de accionistas de conformidad con el artículo 24 de la Ley 1258 de 2008. Por tanto, se ordenare descontar los votos emitidos por uno de los asociados y se declarare la nulidad del nombramiento del representante legal y de la junta directiva, realizados en asamblea de accionistas, además de otras pretensiones. La Superintendencia de Sociedades desestimó las pretensiones de la demanda toda vez que el demandante no solicitó la declaratoria de incumplimiento del acuerdo. 
Además, y en relación con el significado de la frase contenida en el artículo 70 de la Ley 222 según la cual los pactos producen efectos "respecto de la sociedad" y que deben ser "acatados por ella", señaló que: "En criterio del Despacho, la única manera de entender estos efectos, en el contexto de los pactos de votación, consiste en permitir la impugnación de decisiones sociales que fueron aprobadas con el cómputo de votos emitidos en contravención de un acuerdo oponible. Por supuesto que la impugnación solo será procedente en aquellos casos en los que, al descontar los votos emitidos en contra del acuerdo oponible, no se obtenga la mayoría requerida para aprobar la respectiva determinación, en los términos del artículo 190 del Código de Comercio"45.

Además, agregó que la frase "producirá efectos respecto de la sociedad”, empleada por el artículo 70, “...quiere decir que no es posible computar los votos emitidos en contra de un acuerdo oponible, para efectos de conformar la voluntad social, expresada en el seno de la asamblea. En caso de que tales votos se tuviesen en cuenta para aprobar una determinación asamblearia, se habría violado la disposición imperativa del artículo 70, por lo cual podría solicitársele a una autoridad judicial que los descontara del respectivo escrutinio. Una vez removidos tales votos judicialmente, sería preciso evaluar si la decisión impugnada podría subsistir si se toman en cuenta tan solo los votos computados en forma válida. $\mathrm{Si}$ los votos remanentes resultan insuficientes para configurar la mayoría legal o estatutaria requerida, la decisión de la asamblea estaría viciada de nulidad absoluta, conforme al ya citado artículo 190 del Código de Comercio"46.

45 Colombia, Superintendencia de Sociedades, Proedinsa Calle \& Cía. S. en C., contra Inversiones Vermont Uno S. en C., Inversiones Vermont Dos $S$. en $C$., Inversiones Vermont Tres $S$. en $C$., $y$ Colegio Gimnasio Vermont Medellín S.A., Sentencia 801-016, 23 de abril de 2013, Jurisprudencia societaria, 229-254, 251 (Superintendencia de Sociedades, Bogotá, 2014).

46 Colombia, Superintendencia de Sociedades, Proedinsa Calle \& Cía. S. en C., contra Inversiones Vermont Uno S. en C., Inversiones Vermont Dos S. en C., Inversiones Vermont Tres S. en C., y Colegio Gimnasio Vermont Medellín S.A., Sentencia 801-016, 23 de abril de 2013, Jurisprudencia societaria, 229-254, 252 (Superintendencia de Sociedades, Bogotá, 2014). Por otra parte, la Superintendencia de Sociedades también se refirió al incumplimiento y ejecución de los acuerdos de socios en el caso de Beatriz Helena Obando Benjumea contra Oben Muebles S.A. Colombia, Superintendencia de Sociedades, Beatriz Helena Obando-Benjumea contra Oben Muebles S.A., Auto 801-11759, 20 de agosto de 2014, 2 Jurisprudencia societaria, 271-274 (Superintendencia de Sociedades, Bogotá, 2015). Disponible en: http://www.supersociedades.gov.co/procedimientos-mercantiles/normatividad /Documents/Libro\%20Jurisprudencia\%20version\%20final.pdf. El tema objeto de controversia en este caso fue el incumplimiento de un acuerdo suscrito entre los accionistas de Oben Muebles S.A., 
Una situación similar se presentó en el caso de Carlos Alberto Sierra contra Axede S. A. En la demanda se alegó que una elección de junta directiva se había realizado incumpliendo lo pactado en un acuerdo de accionistas en el cual se había convenido la forma de votar durante las reuniones de la asamblea general de accionistas. La Superintendencia de Sociedades determinó que debían descontarse los votos computados en contra de lo previsto en el acuerdo, por lo que decretó la nulidad de la elección de la junta directiva ${ }^{47}$.

\section{LOS PACTOS DE SOCIOS EN LA LEY 1258 DE 2008}

\section{La Ley 1258, sobre sociedad por acciones simplificada, reguló los acuerdos de accionistas en el artículo $24^{48}$. De esta norma se pueden inferir varios aspectos que merecen comentario, sobre todo para}

en virtud del cual se establecieron algunas calificaciones profesionales que debían acreditar quienes se propusieran para ocupar el cargo de representante legal de la sociedad. El incumplimiento alegado consistió en que quien había sido designada como representante legal principal, por la junta directiva, no cumplía con tales requisitos, de forma que la decisión incumplía lo convenido en el pacto. La Superintendencia decretó una medida cautelar ordenando la inscripción de la demanda en el registro mercantil, sin ordenar la suspensión en el cargo de la representante. En sus consideraciones, la Superintendencia se remitió a lo expuesto en el caso de Proedinsa contra Vermont, insistiendo en que la violación de un acuerdo societario puede dar lugar a la ejecución específica del pacto, además de controvertir los votos computados en contra de lo pactado en un acuerdo oponible a la sociedad, con el objeto de impugnar la decisión de la Asamblea.

47 Colombia, Superintendencia de Sociedades, Carlos Alberto Sierra-Murillo y Summertree Trading Corporation contra Axede S.A., Sentencia 801-3, 9 de enero de 2015. Disponible en: http://www. supersociedades.gov.co/procedimientos-mercantiles/Documents/Sentencia\%20No.\%20801-3\%20 (9-ene-2015).pdf

48 El texto de la norma es el siguiente: "Artículo 24. Acuerdos de accionistas. Los acuerdos de accionistas sobre la compra o venta de acciones, la preferencia para adquirirlas, las restricciones para transferirlas, el ejercicio del derecho de voto, la persona que habrá de representar las acciones en la asamblea y cualquier otro asunto lícito, deberán ser acatados por la compañía cuando hubieren sido depositados en las oficinas donde funcione la administración de la sociedad, siempre que su término no fuere superior a diez (10) años, prorrogables por voluntad unánime de sus suscriptores por períodos que no superen los diez (10) años.

Los accionistas suscriptores del acuerdo deberán indicar, en el momento de depositarlo, la persona que habrá de representarlos para recibir información o para suministrarla cuando esta fuere solicitada. La compañía podrá requerir por escrito al representante aclaraciones sobre cualquiera de las cláusulas del acuerdo, en cuyo caso la respuesta deberá suministrarse, también por escrito, dentro de los cinco (5) días comunes siguientes al recibo de la solicitud.

Parágrafo 1. El presidente de la asamblea o del órgano colegiado de deliberación de la compañía no computará el voto proferido en contravención a un acuerdo de accionistas debidamente depositado. Parágrafo 2. En las condiciones previstas en el acuerdo, los accionistas podrán promover ante la Superintendencia de Sociedades, mediante el trámite del proceso verbal sumario, la ejecución específica de las obligaciones pactadas en los acuerdos". Ley 1258 de 2008, por medio de la cual se crea la sociedad por acciones simplificada, 47.194 Diario Oficial, 5 de diciembre de 2008. Disponible en: http://www.secretariasenado.gov.co/senado/basedoc/ley_1258_2008.html 
advertir la relación por similitudes o diferencias con el artículo 70 de la Ley 222 ya analizada.

\section{A. El factor subjetivo y objetivo de aplicación}

A diferencia de los acuerdos regulados por el artículo 70 de la Ley 222 , que como se vio, restringen a los accionistas que detenten la calidad de administradores suscribir el acuerdo, la Ley 1258 no lo hace y por ello puede inferirse que acepta su celebración por parte de cualquiera de los accionistas. Sobre el particular, no deja de resultar curiosa la afirmación de la Superintendencia de Sociedades manifestada en el oficio 220-025702, en el que al referirse a las diferencias entre estas dos regulaciones, señaló que tratándose del acuerdo de accionistas regido por el artículo 24 de la Ley 1258 , “...bien puede ser suscrito el mismo, por un administrador de la sociedad, independientemente que posea acciones o no en la compañía"49. La afirmación es errónea, pues nada en la norma permite entender que el pacto lo podrían suscribir personas que no tuvieren la calidad de accionistas de la sociedad. Otra cosa es, se insiste, que el accionista detente también la calidad de administrador, caso en el cual — se insiste - no le estaría vedado participar del acuerdo, a diferencia de lo que establece el artículo 70 de la Ley 222 de 1995, según se vio ${ }^{50}$.

Por otra parte, aunque en principio la norma parece restringir el campo de aplicación material de los pactos, al circunscribirlos a los acuerdos sobre compra y venta de acciones, preferencia para adquirirlas, restricciones para transferirlas, el ejercicio del derecho de voto y la persona que habrá de representar a la sociedad, cualquier sospecha se difumina, en virtud de que la norma expresamente admite la celebración de acuerdos de accionistas sobre cualquier asunto lícito ${ }^{51}$. De esta forma, no se pueden presentar restriccio-

49 Colombia, Superintendencia de Sociedades, Oficio 220-025702, 29 de abril de 2010. Disponible en: http://www.supersociedades.gov.co/superintendencia/normatividad/conceptos/conceptos-juridicos/ Normatividad\%20Conceptos\%20Juridicos/30575.pdf

50 Correa también advierte este error interpretativo. Ana María Correa-GonzÁlez, Los acuerdos de accionistas bajo la Ley 1258 de 2008, 23 (Pontificia Universidad Javeriana, Bogotá, 2011).

51 Mediante oficio 220-149844, la Superintendencia de Sociedades, al referirse a este punto, consideró que además debe tratarse de pactos que no contraríen los estatutos. "Dichos acuerdos podrán versar sobre cualquier asunto lícito y su utilidad estriba en poder conformar alianzas que funcionen paralelamente a los estatutos, sin contrariarlos (...)”. Colombia, Superintendencia de Sociedades, 
nes bajo el régimen de la Ley 1258, como sí ocurre en la Ley 222 según la regulación del artículo 70 ya citado, que conduzcan a la celebración de pactos que por no referirse al objeto contemplado en la norma, queden excluidos de su ámbito y por ello, sometidos a la disposición del Código de Comercio, esto es: que se trate de un pacto válido pero inoponible. Aquí, valga reiterarlo, a diferencia de lo que sucede con el artículo 70 de la Ley 222, no se restringe que los socios que ostenten la calidad de administradores puedan celebrarlos y tampoco excluye de su campo de aplicación, aquellos pactos que tengan objetos diferentes a los establecidos en la norma. En este mismo sentido, lo destaca Reyes-Villamizar, al afirmar que se trata de uno de los más importantes avances de la Ley 1258 en comparación con lo establecido en el régimen general, que es el del artículo 70 de la Ley 222 ya mencionado ${ }^{52}$.

Adicionalmente, sobre este punto, la Superintendencia de Sociedades, mediante oficios 220-120050 ${ }^{53}$ y 220-121211 ha expresado: "Basta remitirse al contenido del artículo 24 de la Ley 1258 para establecer cuáles son los asuntos susceptibles de estipularse en un acuerdo de accionistas y cuáles eventualmente no lo serían. Consecuente con el criterio de autonomía de la voluntad privada que prima en este nuevo tipo societario al dejar a la libre determinación de los asociados la adopción de la mayor parte de las reglas que habrán de regir la sociedad y las relaciones de los accionistas con ella, el acuerdo entre accionistas puede versar sobre diversidad de asuntos, con la limitación única de tratarse de asuntos lícitos. Por ello, acuerdos para definir conductas de los accionistas en las reuniones de la asambleas, o para establecer cualquier tipo de reglas en materia de administración, o para el ejercicio de derechos

Oficio 220-149844, 10 de noviembre de 2015. Disponible en: http://www.supersociedades.gov.co/ superintendencia/normatividad/conceptos/conceptos-juridicos/Normatividad $\% 20$ Conceptos $\% 20$ Juridicos/OFICIO\%20220-149844.pdf. También con el fin de destacar las diferencias entre la regla contenida en el artículo 70 de la Ley 222 y el 24 de la Ley 1258, en relación con las restricciones contenidas en la primera para los accionistas administradores y el objeto del pacto, puede verse: Colombia, Superintendencia de Sociedades, Oficio 220-025702, 29 de abril de 2010. Disponible en: http://www.supersociedades.gov.co/superintendencia/normatividad/conceptos/conceptos-juridicos/ Normatividad\%20Conceptos\%20Juridicos/30575.pdf

52 Francisco Reyes-Villamizar, SAS. La sociedad por acciones simplificada, 247 ( $3^{\mathrm{a}}$ ed., Legis, Bogotá,

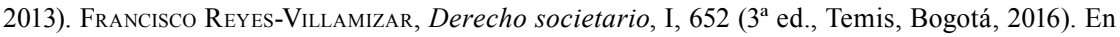
igual sentido, Felipe Cuberos de las Casas, Sociedad por acciones simplificada (SAS). Novedades, aciertos y desaciertos, 116 (Pontificia Universidad Javeriana, Ibáñez, Bogotá, 2012).

53 Colombia, Superintendencia de Sociedades, Oficio 220-120050, 30 de septiembre de 2009. Disponible en: http://www.supersociedades.gov.co 
relacionados con la sociedad o en fin para cualquier otro asunto, como los que de manera enunciativa relaciona la propia ley, son temas de los $[\mathrm{sic}]$ pueden entre otros ocuparse los referidos acuerdos a la luz de la ley"54.

Además de lo anterior, a diferencia de lo que consagra el artículo 70 , en este caso el acuerdo de accionistas de la Ley 1258 no solamente permite hacer pactos para actuar al seno de la asamblea general de accionistas, sino dentro de cualquiera de sus órganos ${ }^{55}$.

\section{B. Los requisitos de forma, oponibilidad y duración}

En cuanto a requisitos de forma y publicidad para efectos de oponibilidad, la Ley 1258 exige solamente el depósito en las oficinas donde funcione la administración de la sociedad. La norma no establece el requisito, que sí se encuentra consagrado en el artículo 70 de la Ley 222 , de que sea entregado al representante legal para su posterior depósito en las oficinas de administración de la sociedad. En este caso, basta el depósito en tales oficinas, omitiendo el requisito de que quien deba recibirlo sea el representante legal.

Por otra parte, a diferencia del régimen de la Ley 222, que como se vio permite la celebración de acuerdos de accionistas sin limitación de tiempo, en la Ley 1258 el artículo 24 sí señala un tope de duración para el pacto que consiste en diez años, prorrogables por otros diez, tiempo que se cuenta desde la fecha de la celebración del acuerdo ${ }^{56}$.

Ahora, en caso de inobservancia del requisito de publicidad, el acuerdo será inoponible ante la sociedad y otros socios que no hubieren participado en el mismo, de forma que en ello se aplicaría lo dispuesto en el artículo 118 del Código de Comercio.

54 Colombia, Superintendencia de Sociedades, Oficio 220-121211, 1 de noviembre de 2009. Disponible en: http://www.supersociedades.gov.co/superintendencia/normatividad/conceptos/conceptosjuridicos/Normatividad\%20Conceptos\%20Juridicos/30887.pdf

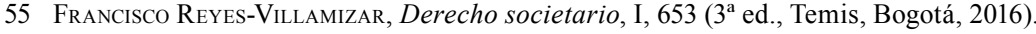

56 Tal como lo señala la Superintendencia de Sociedades en el oficio 220-120050 de 30 de septiembre de 2009. Sobre una visión crítica de esta restricción temporal: Felipe CuBERos DE LAS CASAs, Sociedad por acciones simplificada (SAS). Novedades, aciertos y desaciertos, 116 (Pontificia Universidad Javeriana, Ibáñez, Bogotá, 2012). 


\section{Sanciones por inobservancia del acuerdo}

Los parágrafos 1 y 2 del artículo 24 de la Ley 1258 establecen dos sanciones por la inobservancia del acuerdo. El primero consiste en que el presidente de la asamblea u órgano de deliberación de la sociedad no deberá computar el voto que se haya emitido contrariando el acuerdo de accionistas. El segundo es la posibilidad de ejecutar forzosamente las obligaciones pactadas en el acuerdo, lo que puede hacerse ante la Superintendencia de Sociedades ${ }^{57}$.

Por otra parte, aunque la norma no establece como posible remedio por su incumplimiento la indemnización de perjuicios, para ello deberá acudirse a las reglas generales de la legislación civil y comercial que sí la consagran.

57 Este punto ha sido objeto de crítica por parte de Néstor Humberto Martínez-Neira. En efecto, el autor advierte que debió haberse hecho referencia al proceso ejecutivo para que por esa vía se procediere a ejecutar el acuerdo, y no por el verbal sumario, de naturaleza declarativa. NÉstor HuMBERTO Martínez-Neira, Cátedra de derecho contractual societario, Regulación comercial y bursátil de los contratos societarios, 143 ( $2^{\mathrm{a}}$ ed., Legis, Bogotá, 2014). 


\section{CONCLUSIONES}

Las principales conclusiones sostenidas en este trabajo son las siguientes

- En la práctica del derecho societario, han surgido una serie de acuerdos realizados al margen de los estatutos societarios, mediante los cuales los asociados pretenden regular sus relaciones internas y también entre ellos y la sociedad. La doctrina ve positivamente la existencia de estos pactos como medio de satisfacer de manera plena los intereses de los asociados.

- En el Derecho societario colombiano, se puede asumir que la viabilidad de los pactos societarios se fundamenta en la autonomía de la voluntad, de manera que encuentran cabida además en el artículo 118 del Código de Comercio, norma que si bien establece que frente a la sociedad y a terceros no es admisible prueba de ninguna especie que no sean las escrituras sociales, es viable que los socios realicen acuerdos exigibles entre ellos.

- La Ley 222 de 1995 reguló los pactos de accionistas en el artículo 70 , aunque con un alcance limitado al establecer solamente la viabilidad de los denominados "pactos de voto". De todas formas, la interpretación generalizada ha consistido en señalar que tal regla no impide la presencia de otros pactos que los asociados celebren con base en la autonomía de la voluntad, solamente que presentan el efecto de no ser oponibles a la sociedad o a otros socios, pero sí obligatorios entre los suscriptores del pacto, de forma que en este caso se encontrarán regulados por lo dispuesto en el artículo 118 y las reglas comunes sobre obligaciones y contratos.

- El artículo 70 de la Ley 222 de 1995 presenta también una restricción subjetiva al impedir que los pactos de socios sean celebrados entre quienes detentan tal calidad y son además administradores. En este trabajo se ha demostrado que en caso de violación de tal prohibición, se genera nulidad relativa del pacto.

- La Ley 1258 de 2008 reguló los pactos de socios o accionistas en el artículo 24 de manera más amplia que el artículo 70 de la Ley 222 de 1995, al permitir no solamente los pactos de mando o de bloqueo, sino además todo pacto que tenga objeto lícito. Así también ha permitido la celebración de pactos de socios entre aquellos que además detenten la calidad de administradores. 
- Finalmente, puede concluirse que los pactos societarios están regulados, además de las normas aludidas, por las reglas generales de obligaciones y contratos del derecho común, lo que permite acudir al sistema general de acciones por incumplimiento en caso de inobservancia, como también que sus suscriptores convengan mecanismos de autotutela. 


\section{BIBLIOGRAFÍA}

\section{Libros}

Alessandri-Besa, Arturo, La nulidad y la rescisión en el derecho civil chileno, tomo 1 ( $3^{\mathrm{a}}$ ed., Jorge WAhl, actual., Editorial Jurídica de Chile, Santiago, 2008).

Arrubla-Paucar, Jaime Alberto, Contratos mercantiles. Teoría general del negocio jurídico mercantil (13 ${ }^{\text {a }}$ ed., Legis, Bogotá, 2012).

Claro-Solar, Luis, Explicaciones de derecho civil chileno y comparado, Tomo 11, De las obligaciones, II (Nascimento, Santiago, 1937).

Córdoba-Acosta, Pablo Andrés, El derecho de sociedades y el gobierno de la sociedad anónima: el interés social, órganos, accionistas y administradores (Universidad Externado de Colombia, Bogotá, 2014).

Cuberos de las Casas, Felipe, Sociedad por acciones simplificada (SAS). Novedades, aciertos y desaciertos (Pontificia Universidad Javeriana, Ibáñez, Bogotá, 2012).

Cubides-CAmacho, Jorge, Obligaciones ( $8^{\text {a }}$ ed., Pontificia Universidad Javeriana, Ibáñez, Bogotá, 2017).

Domínguez-Águila, Ramón, Teoría general del negocio jurídico ( $2^{\mathrm{a}}$ ed., Editorial Jurídica de Chile, Santiago, 2012).

Espinosa-Quintero, LeONARdo, Introducción al derecho mercantil (Universidad Sergio Arboleda, Bogotá, 2008).

Gaviria-Gutiérrez, EnriQue, Apuntes sobre el derecho de las sociedades (Señal Editora, Medellín, 2004).

Hinestrosa-Forero, Fernando, Tratado de las obligaciones II. De las fuentes de las obligaciones: el negocio jurídico, volumen II (Universidad Externado de Colombia, Bogotá, 2015).

Madriñán de la Torre, Ramón \& Prada-Márquez, Yolima, Principios de derecho comercial (11 $1^{\text {a }}$ ed., Temis, Bogotá, 2013).

Martínez-Neira, Néstor Humberto, Cátedra de derecho contractual societario, Regulación comercial y bursátil de los contratos societarios $\left(2^{\mathrm{a}}\right.$ ed., Legis, Bogotá, 2014).

Narváez-García, José Ignacio, Derecho mercantil colombiano. Parte general ( $9^{a}$ ed., Legis, Bogotá, 2002).

Narváez-García, José Ignacio \& Narváez-Bonnet, Olga Stella, Régimen legal de las sociedades (Legis, Bogotá, 2016).

Neira-Archila, Luis Carlos, Apuntaciones generales al derecho de sociedades (Temis, Bogotá, 2006).

Ospina-Fernández, Guillermo \& Ospina-Acosta, Eduardo, Teoría general del contrato $y$ del negocio jurídico ( $7^{\mathrm{a}}$ ed., $4^{\mathrm{a}}$ reimp., Temis, Bogotá, 2016).

Peña-Nossa, Lisandro, De las sociedades comerciales (6 ${ }^{\mathrm{a}}$ ed., Temis, Bogotá, 2011).

Pinzón, Gabino, Introducción al derecho comercial (3ª ed., Temis, Bogotá, 1985). 
Pinzón, Gabino, Sociedades comerciales, vol. 1. Teoría general (Temis, Bogotá, 1988).

Reyes-Villamizar, Francisco, Derecho societario, I (3ª ed., Temis, Bogotá, 2016).

Reyes-Villamizar, Francisco, Derecho societario en Estados Unidos y la Unión Europea (4 ed., Legis, Bogotá, 2013).

Reyes-Villamizar, Francisco, Reforma al régimen de sociedades y concursos (2a ed., Temis, Bogotá, 1999).

Reyes-Villamizar, Francisco, SAS. La sociedad por acciones simplificada ( $3^{\text {a }}$ ed., Legis, Bogotá, 2013).

Rovira, Alfredo L., Pactos de socios (Astrea, Buenos Aires, 2006).

Velásquez-Restrepo, Carlos Alberto, Instituciones de derecho comercial (5 $5^{\mathrm{a}}$ ed., Señal Editora, Medellín, 2008).

\section{Colaboración en obras colectivas}

Oviedo-Albán, Jorge, Flexibilización de la constitución de sociedades en Colombia, en Modernización del derecho societario, 59-82 (María Fernanda Vásquez-Palma \& José Miguel Embid-Irujo, dirs., Thomson Reuters, Santiago, 2015).

Reyes-Villamizar, Francisco, Evolución del derecho comercial. Cincuenta años de transformaciones, en Estudios de derecho económico. Tomo I. Instituciones de derecho comercial, 69-98 (José Alpiniano García-Muñoz \& Jorge Oviedo-Albán, coords., Ediciones Jurídicas Gustavo Ibáñez, Bogotá, 2003).

\section{Revistas}

Beltrán-Dávila, David Antonio, Apuntes sobre la obligatoriedad de los acuerdos de accionistas, 41 Foro de Derecho Mercantil, 37-65 (2013).

Henao, Lina, Los pactos parasociales, 25 Revista de Derecho Privado, Universidad Externado de Colombia, 179-217 (2013). Disponible en: http://revistas.uexternado. edu.co/index.php/derpri/article/view/3600/3778

Mejía-Mejía, Darío Alejandro, Los acuerdos de accionistas. Evolución y aplicación en Colombia, 52 Revista de Derecho Privado, Universidad de los Andes, 1-30 (2014). Disponible en: https://derechoprivado.uniandes.edu.co/components/ com_revista/archivos/derechoprivado/pri538.pdf

Oviedo-Albán, Jorge, Una vez más sobre la aplicación de las normas civiles a las obligaciones y contratos mercantiles, 25 Revista de Derecho Privado, Universidad Externado de Colombia, 81-107 (2013). Disponible en: http://revistas.uexternado. edu.co/index.php/derpri/article/view/3597/3691

Paz-Ares, Cándido, El enforcement de los pactos parasociales, 5 Actualidad Jurídica Uría Menéndez, 19-43 (2003). Disponible en: http://www.uria.com/documentos/ publicaciones/1052/documento/03Candido.pdf

Paz-Ares, Cándido, La cuestión de la validez de los pactos parasociales, Número especial Actualidad jurídica Uría Menéndez. Homenaje al profesor D. Juan Luis 
Iglesias-Prada, 252-256 (2011). Disponible en: http://www.uria.com/documentos/ publicaciones/3216/documento/art32.pdf?id=3361

\section{Tesis}

Correa-GonzÁlez, Ana María, Los acuerdos de accionistas bajo la Ley 1258 de 2008 (Tesis de grado, Especialización en Derecho Comercial, Pontificia Universidad Javeriana, Bogotá, 2011). Disponible en: https://repository.javeriana.edu.co/ bitstream/handle/10554/9990/CorreaGonzalezAnaMaria2011.pdf?sequence=1

\section{Normatividad colombiana}

Colombia, Decreto 410 de 1971, por el cual se expide el Código de Comercio, 33.339 Diario Oficial, 16 de junio de 1971. Disponible en: http://www.secretariasenado. gov.co/senado/basedoc/codigo_comercio.html

Colombia, Decreto 4327 de 2005, por el cual se fusiona la Superintendencia Bancaria de Colombia en la Superintendencia de Valores y se modifica su estructura, 46.104 Diario Oficial, 26 de noviembre de 2005. Disponible en: http://www. secretariasenado.gov.co/senado/basedoc/decreto_4327_2005.html

Colombia, Ley 57 de 1887, sobre adopción de Códigos y unificación de la legislación nacional (Código Civil), 7.019 Diario Oficial, 20 de abril de 1887. Disponible en: http://www.secretariasenado.gov.co/senado/basedoc/codigo_civil.html

Colombia, Ley 153 de 1887, que adiciona y reforma los códigos nacionales, la ley 61 de 1886 y la 57 de 1887, 7.151 Diario Oficial, 28 de agosto de 1887. Disponible en: http://suin-juriscol.gov.co/viewDocument.asp?id=1792950,

Colombia, Ley 222 de 1995, por la cual se modifica el Libro II del Código de Comercio, se expide un nuevo régimen de procesos concursales y se dictan otras disposiciones, 42.156 Diario Oficial, 20 de diciembre de 1995. Disponible en: http://www. secretariasenado.gov.co/senado/basedoc/ley_0222_1995.html

Colombia, Ley 964 de 2005, por la cual se dictan normas generales y se señalan en ellas los objetivos y criterios a los cuales debe sujetarse el Gobierno Nacional para regular las actividades de manejo, aprovechamiento e inversión de recursos captados del público que se efectúen mediante valores y se dictan otras disposiciones, 45.963 Diario Oficial, 8 de julio de 2005. Disponible en: http://www.secretariasenado. gov.co/senado/basedoc/ley_0964_2005.html

Colombia, Ley 1258 de 2008, por medio de la cual se crea la sociedad por acciones simplificada, 47.194 Diario Oficial, 5 de diciembre de 2008. Disponible en: http:// www.secretariasenado.gov.co/senado/basedoc/ley_1258_2008.html

\section{Jurisprudencia colombiana}

Colombia, Superintendencia de Sociedades, Beatriz Helena Obando-Benjumea contra Oben Muebles S.A., Auto 801-11759, 20 de agosto de 2014, 2 Jurisprudencia societaria, 271-274 (Superintendencia de Sociedades, Bogotá, 2015). Disponible 
en: http://www.supersociedades.gov.co/procedimientos-mercantiles/ normatividad/Documents/Libro\%20Jurisprudencia\%20version\%20final.pdf

Colombia, Superintendencia de Sociedades, Carlos Alberto Sierra-Murillo y Summertree Trading Corporation contra Axede S.A., Sentencia 801-3, 9 de enero de 2015. Disponible en: http://www.supersociedades.gov.co/procedimientos-mercantiles/ Documents/Sentencia \%20No.\%20801-3\%20(9-ene-2015).pdf

Colombia, Superintendencia de Sociedades, Martín Morelli Socarrás contra Santana Fruits S.A.S. y Javier Barnier González, Sentencia 801-46, 24 de junio de 2014, Bogotá, 2014, Disponible en: http://www.supersociedades.gov.co/procedimientosmercantiles/la-delegatura/jurisdiccion-societaria/jurisprudencia/Documents/ Ultimas $\% 20$ sentencias/Acuerdos $\% 20 \mathrm{de} \% 20$ accionistas/Sentencia $\% 20$ No. $\% 20$ 801-46\%20\%2824-jul-2014\%29.pdf

Colombia, Superintendencia de Sociedades, Proedinsa Calle \& Cía. S. en C., contra Inversiones Vermont Uno S. en C., Inversiones Vermont Dos S. en C., Inversiones Vermont Tres S. en C., y Colegio Gimnasio Vermont Medellín S.A., Sentencia 801-016, 23 de abril de 2013, Jurisprudencia societaria, 229-254 (Superintendencia de Sociedades, Bogotá, 2014). Disponible en: http://www.supersociedades. gov.co/procedimientos-mercantiles/la-delegatura/jurisdiccion-societaria/ jurisprudencia/Documents/Libro\%20Jurisprudencia\%20societaria.pdf

Colombia, Superintendencia de Sociedades, Concepto 220-30490, 1 de julio de 2004. Disponible en: http://www.supersociedades.gov.co/superintendencia/ normatividad/conceptos/conceptos-juridicos/Normatividad $\% 20$ Conceptos $\% 20$ Juridicos/15632.pdf

\section{Conceptos de la Superintendencia de Sociedades}

Colombia, Superintendencia de Sociedades, Oficio 220-19417, 15 de abril de 1997, Doctrinas y conceptos jurídicos 1997, 34-39 (Superintendencia de Sociedades, Bogotá, 1997).

Colombia, Superintendencia de Sociedades, Oficio 220-17650, 18 de abril de 2002. Disponible en http://www.supersociedades.gov.co/superintendencia/ normatividad/conceptos/conceptos-juridicos/Normatividad $\% 20$ Conceptos $\% 20$ Juridicos/4369.pdf

Colombia, Superintendencia de Sociedades, Oficio 220-009238, 11 de marzo de 2004. Disponible en: http://www.supersociedades.gov.co/superintendencia/ normatividad/conceptos/conceptos-juridicos/Normatividad $\% 20$ Conceptos $\% 20$ Juridicos/14309.pdf

Colombia, Superintendencia de Sociedades, Oficio 220-071798, 17 de julio de 2005. Doctrinas jurídicas y contables 1994-2009, 10-14 (Superintendencia de Sociedades, Bogotá, 2009).

Colombia, Superintendencia de Sociedades, Oficio 220-059299, 17 de diciembre de 2007. Disponible en: http://www.supersociedades.gov.co/superintendencia/ normatividad/conceptos/conceptos-juridicos/Normatividad $\% 20$ Conceptos $\% 20$ Juridicos/28212.pdf

Colombia, Superintendencia de Sociedades, Oficio 220-120050, 30 de septiembre de 
2009. Disponible en: http://www.supersociedades.gov.co

Colombia, Superintendencia de Sociedades, Oficio 220-121211, 1 de noviembre de 2009. Disponible en: http://www.supersociedades.gov.co/superintendencia/ normatividad/conceptos/conceptos-juridicos/Normatividad $\% 20$ Conceptos $\% 20$ Juridicos/30887.pdf

Colombia, Superintendencia de Sociedades, Oficio 220-025702, 29 de abril de 2010. Disponible en: http://www.supersociedades.gov.co/superintendencia/ normatividad/conceptos/conceptos-juridicos/Normatividad $\% 20$ Conceptos $\% 20$ Juridicos/30575.pdf

Colombia, Superintendencia de Sociedades, Oficio 220-003037, 6 de enero de 2012. Disponible en: http://www.supersociedades.gov.co/superintendencia/ normatividad/conceptos/conceptos-juridicos/Normatividad $\% 20$ Conceptos $\% 20$ Juridicos/32065.pdf

Colombia, Superintendencia de Sociedades, Oficio 220-149844, 10 de noviembre de 2015. Disponible en: http://www.supersociedades.gov.co/superintendencia/ normatividad/conceptos/conceptos-juridicos/Normatividad $\% 20$ Conceptos $\% 20$ Juridicos/OFICIO\%20220-149844.pdf

Colombia, Superintendencia de Sociedades, Oficio 220-000283, 5 de enero de 2016. Disponible en: http://www.supersociedades.gov.co/superintendencia/ normatividad/conceptos/conceptos-juridicos/Normatividad $\% 20$ Conceptos $\% 20$ Juridicos/OFICIO\%20220-000283.pdf

Colombia, Superintendencia de Sociedades, Oficio 220-246524, 16 de diciembre de 2016. Disponible en: http://bibliotecadigital.ccb.org.co/bitstream/handle/11520/18528/ SuperSociedades-Concepto-2016-N0246524_20161216\%20(1)\%20todas. pdf?sequence $=1$ 
